\title{
Another Law in Indonesia: Customary Land Tenure System Coexisting with State Order in Mutis Forest
}

\author{
Imam Budiman ${ }^{1 *}$, Takahiro Fujiwara ${ }^{2}$, Noriko Sato ${ }^{2}$, Dani Pamungkas ${ }^{3}$ \\ ${ }^{1}$ Graduate School of Bioresource and Bioenvironmental Sciences, Kyushu University, 744 Motooka Nishiku Fukuoka, \\ Japan 819-0395 \\ ${ }^{2}$ Faculty of Agriculture, Kyushu University, 744 Motooka Nishiku Fukuoka, Japan 819-0395 \\ ${ }^{3}$ Forestry Research Development and Innovation Agency of Kupang, Jl. Alfons Nisnoni No. 7B Airnona Kotaraja Kupang, \\ Indonesia 85119
}

Received June 30, 2020/Accepted October 7, 2020

\begin{abstract}
Local wisdom has been coexisting with the state system in several places in Indonesia. The Mountain Mutis Nature Reserve in East Nusa Tenggara province is the strict nature reserves, but a customary land tenure system, called suf, exists so far in the nature reserve. The objectives of this study are (1) to organize the historical territorialization process, (2) to clarify the customary land tenure system and activities for livelihoods by local people, and (3) to discuss the challenges of its land tenure system to manage forests sustainably as well as policy methods to harmonize legal pluralism in Mutis Area. Field observation and in-depth interviews with key informants were employed for data collection, and the collected data were analyzed by a qualitative descriptive method. The findings showed the traditional reward and punishment systems regarding extracting non-timber forest products, grazing livestock, and preventing forest fires were working well for sustainable forest management. However, increased pressure on forests due to future population growth appears to have an impact on the traditional system. It also showed the government officers and local people started some discussions to recognize the suf in the formal legal order. However, there were institutional problems to introduce current state systems. Therefore, it is required to flexibly operate or revise the state laws according to the actual situation to harmonize society between state and people.
\end{abstract}

Keywords: customary forest, protected area, suf, East Nusa Tenggara Province

*Correspondence author, email: ibudiman99@gmail.com

\section{Introduction}

In the colonization era, forest areas were gazetted after the territorial declarations, and those forests were managed based on scientific forestry (Peluso, 1992; Sivaramakrishnan, 1995). Also, colonial governments designated some forests as protected areas without prior discussion with local communities. Vandergeest \& Peluso (2015) term such forests area as a political forest.

In Indonesia, in the mid-19th century, the Dutch colonial government was managing the forests to meet the timber needs of the shipbuilding industries (Nurjaya, 2005). At that time, there were many stands of teak along the north coast of Java island. However, after the depletion, several rules were issued to prohibit the cutting of teak trees. Then, teak had been used to make railroad tracks until the early 1930 s (Stroomberg, 2018). The Dutch colonial government conducted forest management with a clear-cutting system and modern silvicultural rules derived from European countries, especially in Germany (i.e., scientific forestry).

The end of the $19^{\text {th }}$ century was a moment of awakening of conservationists in the Dutch colonial government. Starting from pioneering conservation areas in several areas on Java island, a conservation area was established in the form of a nature reserve (natuurmonumen) (Yudistira, 2014). The conservation area on Java was initially established with an appointment system by forestry authority through the Dutch colonial government decree. On 22 July 1912, the Netherlands Indies Nature Protection Association was established. This organization consisted of a group of Dutch people dominated by scholars, especially in the field of biology (naturalists), researchers, and environmentalists in the Dutch East Indies (Indonesia at that time). With Dr. SH Koorders as Chairman, this organization actively approaches the Dutch government to protect areas that have the potential of the natural wealth of plants and animals. The area is proposed to be designated as the nature reserve. As an initial stage, they proposed 12 locations in Java as the nature reserves at the beginning of its activities (MoEF, 2020).

After the independence of Indonesia in 1945, the Indonesian government inherited the nature reserve formed in the Dutch colonial era. The establishment of new conservation areas was originated from government initiatives and supports of the conservationists with ideas to preserve animals and plants wildlife (Jepson \& Whittaker, 2002). In addition to the new conservation areas, Hidayat et al. (2018) explained that the developmentalism changed the 
forest management regime in Indonesia. Initially, the new order government enacted the "unity in diversity" principle, but which gradually reduced the recognition of political rights that might protect the multicultural and ethnic diversity. The new order regimes took control of $70 \%$ of Indonesia based on Mining Law 1967 and Forestry Law 1967, then gave the area for commercial utilization through concession (mining and timber company) as well as conservation area establishment. "Heads of customary communities and villages who refused to release their customary forest lands for this main objective of 'development' were targeted for intimidation and often jailed". The new order regime often grabbed lands of customary communities without any written legal documents. Besides, massive small-scale agricultural activity through the transmigration program also eroded customary lands (Hidayat et al., 2018). Consequently, the conflicts between the state and local communities frequently happened.

The National Human Rights Commission (Komnas HAM) mentioned that there were at least 39 major agrarian conflicts with indigenous people or customary communities over their customary territory within the forest areas (Komnas HAM, 2016). Some of them occurred between companies and indigenous peoples over the lands that the state granted concession rights to the companies (McWilliam, 2006). There were also many conflicts between indigenous peoples and state forest managers in the conservation areas in the name of professional conservation, which is managing protected areas based on scientific forestry systems characterized by the zonation system and prohibiting or strictly limiting human activities in the designated conservation area (Lund \& Rachman, 2018).

In several regions in Indonesia, customary communities have their local customs and laws, and those customary laws have been coexisting with state laws. Historically, this situation was started on Java island since the Dutch colonial government introduced its Western Law in the $18^{\text {th }}$ century (Fasseur, 2007). A similar situation can be found in the small Sundanese archipelago consisting of the provinces of Bali, West Nusa Tenggara, and East Nusa Tenggara (Suartika, 2007; Sopian, 2015; Riggs et al., 2016). The legal pluralism is often contested in several sectors, mainly in the judicial system (Griffiths, 2015) and tenurial system (Wibowo \& Murdiati, 2013). For example, the national laws contested with Sharia law based on the Islamic religion in Aceh special region as well as traditional laws based on culture and local beliefs (Salim, 2010; Crouch, 2013).

The managing conservation area has been facing new dynamic challenges since the indigenous people and customary communities living mainly around the forest started struggling to restore their customary territorial rights. The people and communities, facilitated by the Indonesian Indigenous People Alliance (Aliansi Masyarakat Adat Nusantara), have been more active since the constitutional Court Decision No.35 was enacted in 2012. According to the Directorate General of Conservation of Natural Resources and Ecosystems, there were 134 units of 777 customary forests proposed by AMAN located in state conservation areas covering more than 1.6 million hectares across Indonesia until 2018. Figure 1 shows the traditional land and its existence in Modern Indonesia.

Territorialization is one of the forms of colonial legacy related to the land ownership system. Some earlier studies discuss territorialization and legal pluralism in the excolonized country, particularly in Asia and Africa. Griffiths (1986) and Merry (1988) laid the foundation of ideas about legal pluralism, especially what happened in the former colonial countries. There are also various studies about legal pluralism on water rights (Meinzen-Dick \& Nkonya, 2007), fisheries (Jentoft et al., 2009), and forestries (Sivaramakrishnan, 1995; Graziani \& Burnham, 2005; Benjamin, 2008).

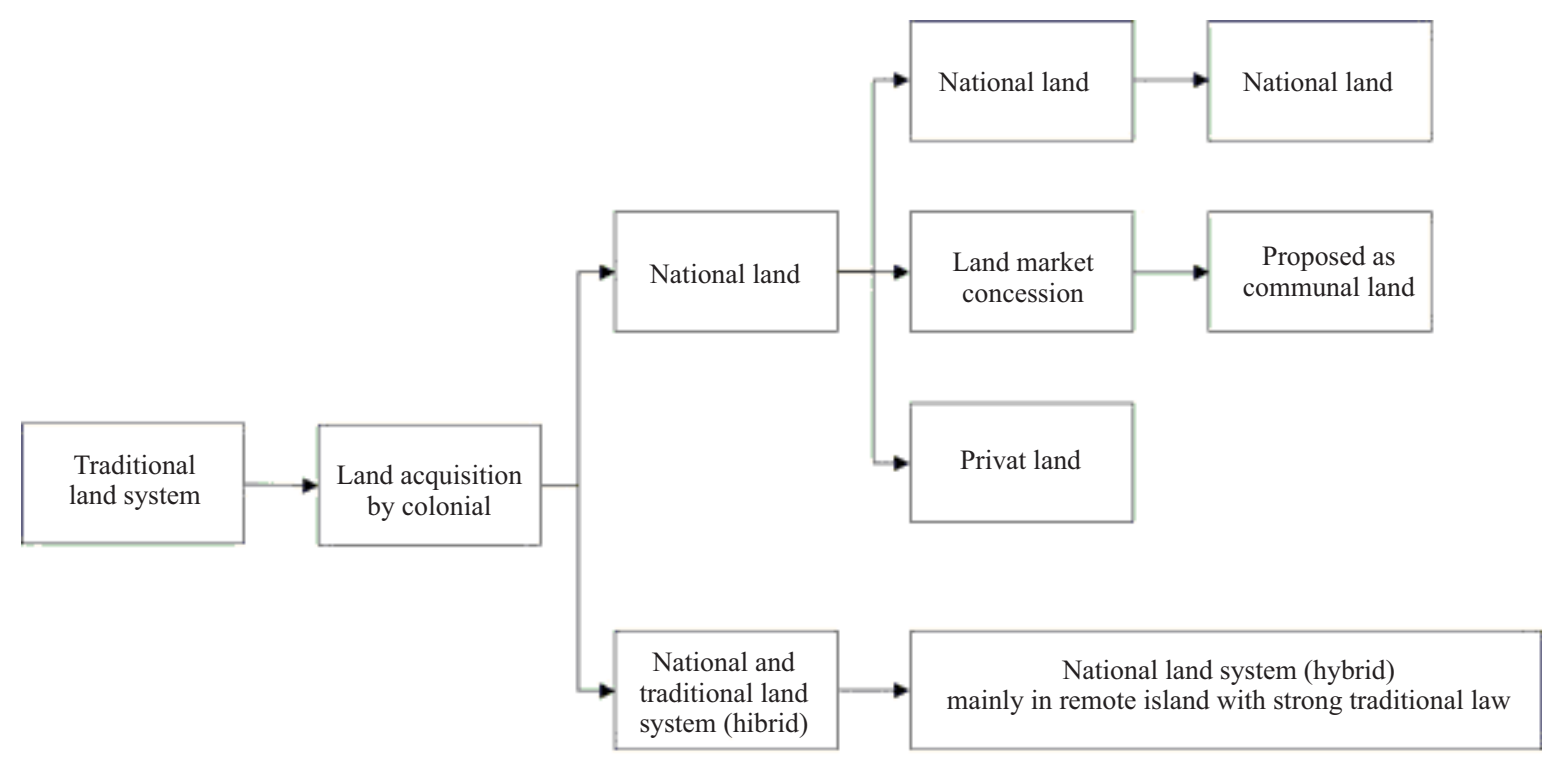

Figure 1 The traditional land and its existence in modern Indonesia. 
The study topic of territorialization by the colonial government and legal pluralism has attracted scholars from more than one hundred years ago in Indonesia. According to Vandergeest \& Peluso (1995), "territorialization" is defined as "excluding or including people within particular geographic boundaries, and about controlling what people do and their access to natural resources within those boundaries". The authority decided activities to be allowed or prohibited in the territorialized area through the territorialization process. When Indonesia was still the Dutch colony, van Vollenhoven introduced the concept of legal pluralism to explain the coexisting of customary law (adatretch) and colonial law. Griffith (2015) defines the legal pluralism as "the coexistence of more than one regulatory order in society". Meanwhile, Burns (2004) calls it "Leiden Legacy". The concept of legal pluralism enables us to distinct rules and procedures for specific groups, such as the indigenous people or ethnic groups (Merry, 1988). In Java, Peluso (1992) explored extensively about legal pluralism and territoriality. Meanwhile, Crouch (2013) classified studies on legal pluralism in Indonesia into three types: Islamic Law, religious courts, and customs and regional case studies.

The East Nusa Tenggara province is one of the provinces where local customs and customary laws have been existing. The Mountain Mutis Nature Reserve is one of the strict nature reserves in the East Nusa Tenggara province. A traditional land tenure system, called suf, exists in the nature reserve. This dual legal system (i.e., the coexistence of the state laws and customary laws) in Timor Island has been in place since the introduction of Western Law by the Dutch government.

The earlier studies in Mountain Mutis Area discussed the traditional agroforestry system, land-use change, and livelihood aspects of the native inhabitants. For example, Agu \& Neonbeni (2019) classified the traditional high-land agroforestry model in the West Miomaffa area adjacent to the east side of the Mountain Mutis Nature Reserve into three models: kono agrosilviculture model, suf silvopastur model, and poan agrosilvopastur model. Pujiono, et al. (2019) showed the land-use changes and deforestation in the Mutis area over three decades using GIS analysis. Riwu Kaho \& Marimpan (2014) mapped land fire regime based fire patterns in the natural reserve. Dako et al. (2019) specified the benefits of the Mutis forest area for the income of the community around the forest, such as firewood and carpentry wood and showed the food consumption patterns to maintain food security around the Mount Mutis Nature Reserve. Meanwhile, Kurniadi \& Rumboko (2016) focused on livestock grazing around the Mutis area and the acceptance of local people to the forest policy implemented by the forestry agency in the Mutis area. They reported that local communities refused the governmental regulation to ban silvo-pastural activities in the state-protected forest because it was not in accordance with their customary laws inherited from generation to generation (Kurniadi \& Rumboko 2016).

The study of traditional land tenure in the Mutis area is essential to establish effective forest policy for the sustainability of forest conservation and local livelihoods. However, numbers of previous studies focusing on traditional land tenure are very few. Therefore, a study that clarifies the current situation and challenges of the traditional land tenure system is strongly required, and it can contribute to a nationwide discussion on the customary forest in Indonesia.

The objectives of this study are (1) to organize the historical territorialization process in the Mutis area, (2) to clarify the traditional land tenure system and activities for livelihoods by local people in the Mutis area, and (3) to discuss the challenges of the traditional land tenure system to manage forests sustainably as well as policy methods to harmonize legal pluralism in Mutis Area.

\section{Methods}

Study site The East Nusa Tenggara province has approximately 1.3 million inhabitants, and their main occupation is agriculture and forestry. As of 2019, the average net monthly income from the informal sector (e.g., agriculture) was only about IDR1 million (USD72), and it was one of the lowest incomes in Indonesia (BPS, 2019). Thus, poverty is still a significant problem in the East Nusa Tenggara province.

The Mountain Mutis Nature Reserve is located across the Timor Tengah Selatan district and Timor Tengah Utara district. The total area is $12,315.61$ ha. The $80.29 \%$ area is located in Timor Tengah Selatan District, and the $19.71 \%$ area is located in Timor Tengah Utara District. The top of Mt. Mutis is $2,427 \mathrm{~m}$, and the reserve is mainly located between $1500 \mathrm{~m}$ and $2000 \mathrm{~m}$. The dominant vegetations are Eucalyptus alba and Casuarina junghuhniana below $1500 \mathrm{~m}$ and Eucalyptus urophylla (locally known as ampupu) below 2,000 m (Kurniawan \& Iswandono, 2018). IUCN has seven categories of the protected area, and the Mountain Mutis Nature Reserve is classified as a strict nature reserve (Ia) whose primary objective is to protect biodiversity and geological aspects. Based on IUCN rules, strict nature reserve means that the area is basically limiting "human visitation." Its "utilization and impacts are strictly controlled and a limiter to ensure the protection of the conservation values" (IUCN, 2008). The forested slopes of Mutis Mountain area is a critical watershed for the Timor island, and it plays a substantial role in the culture and village economy around the reserve (Lentz \& Bowe, 1998).

Fourteen villages are bordering the Mutis Nature Reserve. The education level of the villagers is low, and their main occupation is livestock rearing and farming based on dry-land crop rotation systems (Fisher et al., 1999). The forests are vital for them as a place for livestock grazing, collecting honey from wild bee nests, and other non-timber forest products. Those activities generate additional income for them. Besides, the villagers use water from the forest for cooking, drinking, bathing, and they collect building materials and fuel woods from the dried trunks and branches of naturally fallen атрири trees (Lentz \& Bowe, 1998).

We selected the Fatumnasi village for the data collection. The Fatumnasi village is directly adjacent to the Mountain Mutis Nature Reserve and has the most extensive area in the nature reserve administratively. The village is adjacent to two conservation areas with different state jurisdictions. The west side of the village is adjacent to the Mountain Mutis Protected Forest managed by the Mutis Forest Management Unit under the control of the Provincial Government Forest Service. This forest management unit (FMU) has 115,380 
hectares, and its management started in 2012. They have divided the area into the three FMU based on the division of district administrative area. The east side of the village has a border with the Mountain Mutis Nature Reserve that the Dutch government designated initially as a forest cover to protect unique ecosystems with атрири and conserve water in 1928 (Kurniawan \& Iswandono, 2018). Therefore, this area is also one form of the territorial process carried out by the Dutch government.

Data collection and analysis We conducted a field survey in October 2018 and March 2019. We conducted field observation to understand the situation of how the customary legal system works in the village. Besides, to understand the social and economic perspectives of local people, we conducted in-depth interviews with keys informants who were involved in the Mutis Timau Nature Reserve activities. Referring to Roth (2011) that discussed the issue of interaction between formal and traditional institutions, we selected the key informants based on their social role in the community, the closeness of daily interactions with the forest, and their participation in forest management. The interviewees included officers of central and local government agencies, a staff of Non-Government Organizations (NGOs), and leaders of customary communities. Table 1 shows the breakdown of the key informants interviewed in this study. The interview items were as follows: 1) the progress and current condition about customary communities in the Mountain Mutis area, 2) the status, problem, and land dynamic in the Mountain Mutis area, and 3) image, perception, and utilization from the suf area located inside the Mountain Mutis Nature Reserve.

In parallel with the interviews, we collected secondary data, such as statistical data and related documents. The collected secondary data were including the profile and demographic data of Fatumnasi village, a map showing boundaries among protected area, nature reserve, and villages (Figure 2), and agreement on access to customary area inside of Mountain Mutis Nature Reserve among a chief of the Mountain Mutis Nature Reserve Resort, a village head of Fatumnasi Village, a religious leader, and a traditional leader.

We analyzed the collected data by qualitative descriptive analysis to "describe systematically and accurately the facts and characteristics of a particular population or area/conditions" (Wirartha, 2006). Also, we employed the legal pluralism theory reconceptualizing by Griffiths (1986), which defines the presence in a social field of more than one legal order.

\section{Results}

Territorialization process in Mutis area The customary communities around the Mountain Mutis area have existed for a long time. When the Dutch government first came to the Timor Island in 1653, there was a small local princedom in Timor Tengah Selatan district. Then, the princedom was transformed into three autonomous regions (swapraja): Amanatun, Amanuban, and Mollo. The people of the three autonomous regions were a part of the Atoni ethnic group that was the largest ethnic group occupied the western part of Timor island (Nordholt, 1971). The name of Atoni comes from the word of Atoni Pah Meto (= the people of the dry land) (Nordholt, 1971). At that time, while the Portuguese governed the east part of the Timor island, the Dutch governed mainly Kupang city in the west part of the Timor island. The Dutch government devoted the sandalwood trade that was the mainstay commodity of the Timor island at that time and enacted many regulations for the sandalwood trade system; however, they did not interfere much in traditional matters of the interior (Nordholt, 1971).

The territorialization on the Mount Mutis began with the enactment of Mutis Gebergte, zulfbestur No. 4/1 in 1928, that established a forest covers to protect the ecosystem and conserve water (BBKSDA NTT, 2019). After the independence, the Indonesian government, through management under the authority of the Governor of the East Nusa Tenggara province, took over this area in 1974. Although there have been several changes in management status, the traditional land management system has not changed (Table 2). The traditional land management system is hereditary in one clan group (communal family right).

Traditional land tenure system in Mutis area The traditional land tenure systems have been coexisting with the state forest system in the Mutis Nature Reserve. Before designated as the forest covers by the Dutch government, several dominant clans living around the Mount Mutis area, called pah tuaf, controlled the lands. They were elders of the Mollo people. The Fatumnasi village is composed of four large clans (i.e., Anin, Bay, Oematan, and Taklale), and they have inherited and maintained the culture of the Mollo people in several aspects. One of them is traditional land tenure

Table 1 List of key informants interviewed in this study

\begin{tabular}{lll}
\hline \multicolumn{1}{c}{ Government } & Non-Government & \multicolumn{1}{c}{ Customary Community } \\
\hline$\bullet \quad$ An officer of East Nusa Tenggara & $\bullet$ A Staff of WWF East Nusa & $\bullet$ Village heads \\
Conservation of Nature Resources & Tenggara & $\bullet$ Elders of customary groups \\
office & & $\bullet$ A leader of a young people's \\
- An officer of East Nusa Tenggara & & group \\
Province Forest Office & & A descendant from the former \\
- An officer of Forest Management & & Kingdom of Mollo \\
Unit of Mutis Timau & & A leader of honey bee farmers' \\
An officer of Regional Planning & & group \\
Agency in Timor Tengah Selatan & & \\
District & & \\
\hline
\end{tabular}




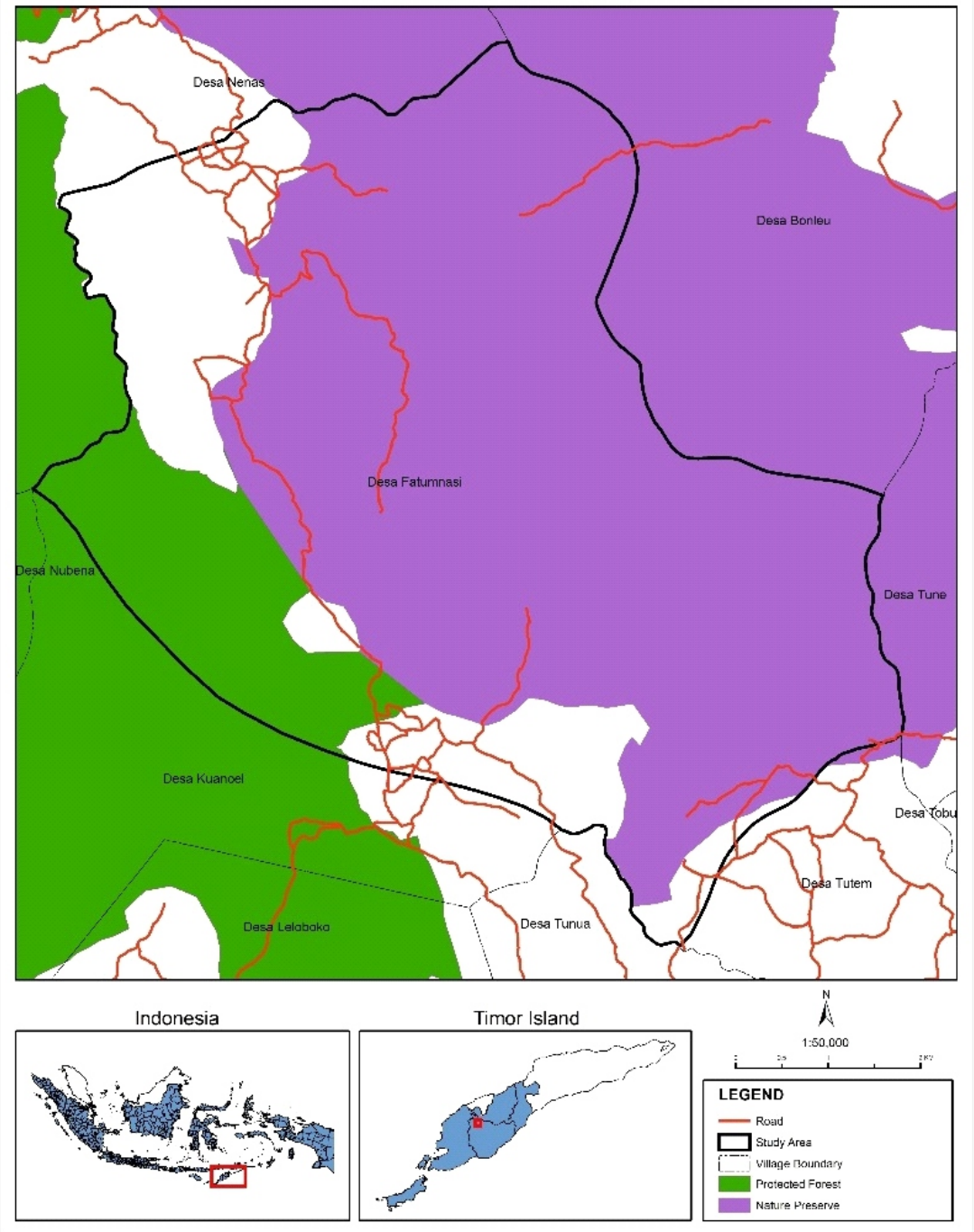

Figure 2 Study site. Source: Geospatial Information Agency (2019).

systems with an imaginary land territorial system called suf. Ormeling (1955) defined suf as authority for the management of natural resource areas owned by each tribe or indigenous clans headed by an amaf (customary head).

All customary community around the Mutis area recognizes the suf, but nobody knows precisely so far when and where suf system began. Official data collection on suf also has never been conducted by the all level government, including central, provincial, and local government institutions, because the legal structure of the government does not formally institutionalize the $s u f$. What is sure that the suf system has been passed down from generation to generation to date by a verbal tradition. In 2018, WWF Nusa Tenggara conducted a field survey to identify areas of $s u f$ in the Mutis mountain forest area, and they found that 176 families actively used suf areas for their needs for livelihoods.

According to the customary leaders in Fatumnasi village, Bonleu village, Mutis village, and Nenas village, the villagers who can do such activities were limited to family groups or clans with customary rights for suf. In other words, migrants, such as government officials assigned to the village (e.g., teachers and principals of schools), do not have the right to do such activities in suf areas. However, migrants who marry with villagers with the sufcan use their suf area. The villagers can not transfer the customary rights of suf to other persons because it is a communal right. Therefore, family members who move out of the village lose rights for the suf, but they can regain the right when they returned to the village.

The suf areas had direct borders with the state conservation area and protected area as well as villages, especially in the case where the suf existed in the enclave area. The recognition of the local people for the borders between the state-owned territories and their customary territories was ambiguous. As observed by Ormeling (1955), its imaginary boundaries usually were confirmed by natural borders such as rivers, large trees, or large rocks. Some of the suf areas were overlapping with the state forest.

The governmental officers regarded the suf as one of the causes of encroachment in the nature reserve. They mentioned that 71 hectares in 2009 and 64 hectares in 2012 
Table 2 Territorialization process in Mutis Mountain

\begin{tabular}{cl}
\hline Year & \multicolumn{1}{c}{ Event } \\
\hline Before 1928 & The land is traditionally owned by landlords: "pah tuaf", passed down in one family group \\
1928 & Mutis gebergte (Mutis Mountain), designated as forest cover by the Dutch Government \\
1945 & Indonesian Independence \\
1974 & Forest cover, managed by Provincial Forestry Office \\
1978 & Gazettement by Brigade VIII of East Nusa Tenggara Forestry Planology (153.227,68 ha) \\
1983 & $\begin{array}{l}\text { The management of the Mutis Timau area is divided into the Mutis Nature Reserve Area and the } \\
\text { Mount Timau Protection Forest 13,392,507 ha }\end{array}$ \\
1996 & $\begin{array}{l}\text { Mutis Timau Nature Reserve covering an area of 17,211.85 ha with 15,155.19 ha located } \\
\text { within the TTS Regency area and 2,056.76 ha located in the TTU Regency area }\end{array}$ \\
& $\begin{array}{l}\text { Mutis Timau nature reserve area of 12,869,115 ha (area of GIS), Decree of the Minister of Forestry } \\
\text { Number: 423/Kpts-II/1999 }\end{array}$ \\
& $\begin{array}{l}\text { The Mutis Mount Nature Reserve area is 12,315.61 ha. South Central Timor (TTS) District } \\
\text { covering an area of 9,888.78 ha (80.29\%) and North Central Timor (TTU) District covering an area of }\end{array}$ \\
2,426.83 ha (19.71\%). \\
The East Nusa Tenggara Center for Conservation of Natural Resources and WWF initiated the \\
153,227.68 ha Mutis Timau Forest Group to become a national park
\end{tabular}

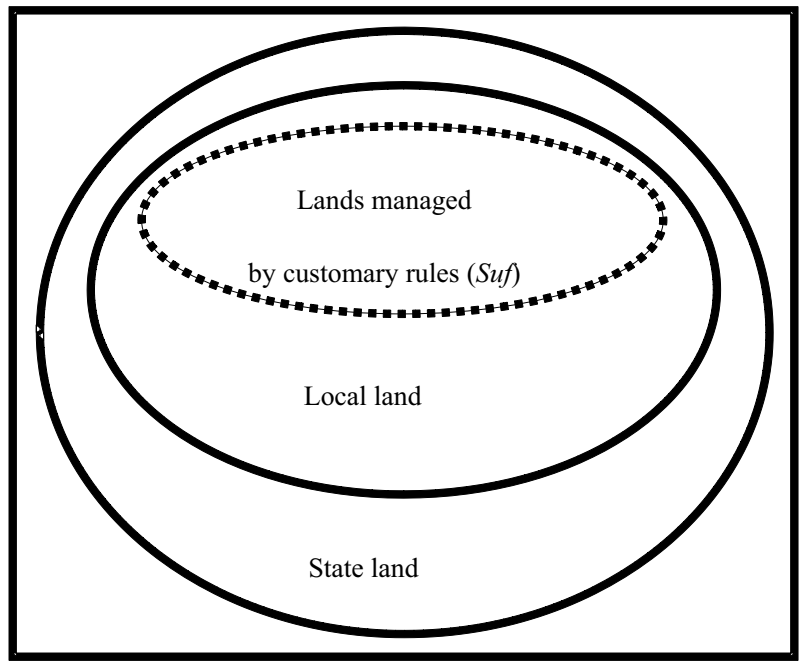

Figure 3 Overlapping legal order for territories in the Mutis area. Source: Adapted from Meinzen-Dick \& Nkonya (2007).

of forest encroachment occurred in the nature reserve. Most squatters were coming from two villages in the east part and south part of the forest area, and they were carrying out farming activities to fulfill daily needs. The governmental officers did not consider that those encroachments were disturbing the forest ecosystem. On the other hand, they were employing moral suasion for the local people to leave the encroached area and recognize that the area belongs to the state.

Figure 3 shows the overlapping legal order in Mutis Mountain. The dot-line means the customary area determined by the customary rules and laws. The customary area is existing inside state land, and the customary rules have strongly been influencing people living in the Mutis area. The local and national governments had not recognized those customary rules as the formal legal order for a long time. However, recently, they started discussions to recognize the suf in the formal legal order. According to the officials of the nature reserve, they proposed several alternatives, such as nature tourism parks and national parks, to change the function of the area. However, until now, no final decision has been made, and current status remains the nature reserve.

In this situation, a chief of the Mountain Mutis Nature Reserve Resort, a village head of Fatumnasi Village, a religious leader, and a traditional leader signed a mutual agreement on the access of the suf area in the Mutis area on 7 August 2019. The agreement had two primary purposes: (1) to maintain the sustainability of the forests in Mountain Mutis and (2) to improve the prosperity of the villagers in Fatumnasi Village. The contents included in the agreement were as follows: (1) to set the camping location for visitors in a predetermined location in the Fatumnasi village field in order to generate financial income for the villagers, (2) to 
regulate the collection of forest moss, which is permitted only in protected forest areas, not in conservation areas (e.g., the harvesting of this Eucalyptus urophilla moss must also not be carried out by cutting down or injuring the tree, but by using a wooden jug or bamboo), (3) to continue the collection of NTFPs (forest honey) with traditional rituals, and (4) to follow the village regulations formally.

Traditional activities for livelihoods in $\boldsymbol{S u f}$ The elders of customary groups testified that the local people believed that they had the right to do anything except cutting trees in their suf. There were some traditional activities by the local people for livelihoods for generations under suf system in the Mutis area. One of them is a honey collection.

The local people have collected honey in their suf for generations. The yield of honey varies in every season. Generally, the honey harvest season is three months after the flower season. Wind and rain are the main factors affecting the honey yield. When honey-producing trees have enough flowers to feed the bees, the bees take nectar from flowers. However, when winds are strong (generally from the west), flowers are blown away, and the bees have no food. Irregular rain also causes uneven flowering. Consequently, the bees eat honey stored in their nests, and it results in hives that do not contain honey.

They have some traditional rituals based on their customs to preserve the nature reserve. For example, before collecting honey, the local people hold the rituals and pray for their safety to their ancestors during the honey collections. After collecting honey, they have the rituals to pray again to their ancestors for a rich honey collection next season. They have a principle for a sustainable honey bee harvesting, called Ikepale. It means taking only parts of honey. They do not harvest all the colonies of the honey bee and collect only the amount they need under the Ikepale system. Also, they do not harvest the colonies on the small branch. This customary system is useful in regenerating honey for next season and maintaining the sustainability of honey collection.

Customary sanctions on forest fire The local people burn their suf to get fodder. However, sometimes the fires are uncontrollable and spread beyond their suf. We also witnessed many fires that occurred in the nature reserve and protected forest area during our field data collection in the heavy dry season of October and November. According to the Mutis Resort Management Office, 14 fires happened during the peak of the dry season in 2019. There were three leading causes of the fires: (1) accidental fire when getting young grass, (2) accidental fire when hunting animals, and (3) spreading fire when burning gardens.

The Natural Resource Conservation Law in 1990 and the Forestry Law in 1999 provide for imprisonment or fines for perpetrators of forest fires. Meanwhile, the customary rules also provide sanctions for perpetrators without being affected by the state legal sanctions. As a concrete example, on 6 November 2019, a traditional ceremony was held to give customary penalties against a villager who burned up 106.3 hectares of forest and many trees, including 700 aтрирu trees, in Pubasu village. The perpetrator declared to promise not to repeat the deed done through the sealed declaration signed by him at the traditional ceremony. This ceremony was also witnessed by village officials, customary leaders, and nature reserve officers. Besides, the perpetrator had to provide some material for conducting the traditional ceremony, which cost nearly IDR4,000,000 (around USD300).

Table 3 shows the comparison between national law and customary law in the Mutis area. According to the Act Number 5 of 1990 on Natural Resource Conservation and its derivative regulation, the activities in the nature reserve is strictly prohibited. Only several activities are accepted with special conservation area entry permits called SIMAKSI (Surat Izin Masuk Kawasan Konservasi/entry permit to the conservation area), such as research and development, movie making, and journalistic activities. Concerning the border of the area, the formal regulation only acknowledges the forest area based on the gazettement process by the Ministry of Environment and Forestry. The fine and imprisonment are imposed on violators as penalties. The dominant figure on managing the forest is forestry officers in the Mutis Nature Reserve Unit. In contrast, the main source of customary law $(s u f)$ is oral speech which is passed down through customary elders. Based on the customary law, the activities, such as NTFPs and cattle grazing, are limited and permitted. In terms of the border area, local people have "imaginary" border determined by the natural boundary, such as trees, rivers, and big stones, based on the customary law. The fine and traditional sanction are imposed on violators, and the elders are dominant figures in the traditional laws.

\section{Discussion}

The suf have been coexisting with the state system until today. The findings showed that the local people believed that they had the right to do anything except cutting trees in their suf areas. They had conducted some traditional

Table 3 Comparison between national law and customary law in the Mutis area

\begin{tabular}{lll}
\hline \multicolumn{1}{c}{ Parameter } & \multicolumn{1}{c}{ National Law } & Customary Law (suf) \\
\hline Source of law & Act Number 5 of 1990 about Natural Resource Conservation & Oral speech/agreement in the indigenous community \\
Access & Strictly Prohibited & Limited utilization \\
Border area & Based on Gazettement Process & Following suf areas per family group \\
Sanctions and penalties & Fine/imprisonment & Fine/traditional sanction \\
Dominant figure & Forestry officer of Mutis nature reserve unit & Elders \\
\hline
\end{tabular}


activities for livelihoods, such as honey collection, for generations under the suf system. Some of the suf were overlapping with the state forest. Even though the government officers regarded the suf system as one of the causes of encroachment in the nature reserve, they did not consider that those encroachments were disturbing the forest ecosystem.

Myers et al. (2017) explain that conservation areas are a vital area of contestation between the state and customary communities. As the history of Indonesia shows, the first conservation areas were formed by the Dutch government in the colonial era, and the Indonesian government inherited those conservation areas after independence in 1945. In the Mount Mutis area, territorialization began with the enactment of Mutis Gebergte, zulfbestur Number 4/1, in 1928. Simultaneously, the Dutch colonial government established the conservation area, called forest covers, to protect the ecosystem and conserve water in the Mount Mutis area. Currently, the Mountain Mutis area consists of two conservation areas with different state jurisdictions: (1) the Mountain Mutis Protected Forest managed by the Mutis Forest Management Unit under the control of the Provincial Government Forest Service and (2) the Mountain Mutis Nature Reserve that the Dutch government designated initially as the forest covers.

As Kurniadi \& Rumboko (2016) reported, the governmental policies that restrict access of local communities to state forest areas caused resistance from the local community that depended on access to state forest areas for their livelihood, such as grazing. In other words, the designation of conservation areas is against the will of the local community, and such cases occurred in the Bukit Baka Bukit Raya National Park in Kalimantan and Lore Lindu National Park in Sulawesi (Myers \& Muhajir, 2015; Maiwa et al., 2018). In comparison with the management system which was more accommodative to human activity, Hayes (2006) pointed out that conservation areas with modern scientific systems (e.g., protected area and national parks), which prohibited many activities of local people, were not always an effective way for promoting local conservation. Therefore, it is required ways to harmonize nations and communities around protected areas.

Sopian (2015) mentions that the legal pluralism application is intended to maintain order and harmony in society. In the Mount Mutis area, the local people had a principle for a sustainable honey bee harvesting, called Ikepale. They do not harvest all the colonies of the honey bee and collect only the amount they need based on the customary rules. Besides, they had the customary rules providing sanctions for perpetrators of forest fire without being affected by the state legal sanctions. Our findings showed the perpetrator declared to promise not to repeat the fire in front of village officials, customary leaders, and nature reserve officers at the traditional ceremony. The rights for suf are limited to family groups or clans in the village. In other words, the villager must continue to live in the village to retain their rights. Trust from other villagers is an essential condition to live in the village, and consequently, they must follow the customary rules to keep it. Therefore, such customary rules and punishment systems appear effective ways for sustainable forest management.

In contrast, there are some concerns about the effects of customary rules on sustainable forest management. The East Nusa Tenggara province is composed of many small islands, and the current population density is not high. Also, the local people collect only the amount they need under the Ikepale system. While the current forest resource use is well maintained under this condition, however, future increased pressure on the forest due to the growth of population and commercialization of honey collection could affect the use of suf. Also, it may cause friction between the local people and the governmental officers.

As we discussed above, it appears that the legal pluralism approach is one of the ways to harmonize nations and communities around protected areas. On the other hand, there are some institutional challenges to apply the legal pluralism approach in the Mount Mutis area. The suf have been coexisting with the state system until today, and all customary community around the Mutis area recognizes the suf; however, nobody knows precisely so far when and where suf system began. The legal structure of the government does not formally institutionalize the suf so far, but recently there are some policy movements to position the suf in the legal structure. For example, the Minister of Environment and Forestry Regulation on Gazettement of Forest Area allows excluding the customary area from the state forest. However, written authentic evidence is required for that. The suf system has been passed down from generation to generation to date by a verbal tradition. Therefore, the ministerial regulation can not apply to the suf.

The findings also showed that recently, the government officers and local people started some discussions to recognize the suf in the formal legal order, such as nature tourism parks and national parks system. However, their introduction still seems to need to solve some institutional problems. The suf area in the Mutis area is composed of the nature reserve and protected forests. In contrast, the nature tourism park targets nature reserve only and cannot be introduced into protected forests. Another possible solution is the social forestry scheme. However, even though social forestry can introduce in protected forest areas, it cannot introduce in the nature reserve area. The current policies are not in line with the actual situation in the Mutis Area. Therefore, bridging the gap remains a policy challenge to harmonize the legal pluralism.

\section{Conclusion}

This study organized the historical territorialization process and clarified the traditional land tenure system, called suf, in the Mutis area. The historical process forms the legal pluralism between state and people. The present local and national governments had not recognized those customary rules as the formal legal order for a long time; however, the suf have been coexisting with the state system until today. Recently, they started discussions to recognize the suf in the formal legal order. The legal pluralism is essential to manage forest resources sustainably and harmonize society between state and people, especially in places where the local custom and laws are still maintained well. Therefore, it is required to flexibly operate or revise the 
state laws according to the actual situation to promote forest policy on customary forests.

\section{Acknowledgment}

This work was supported by JSPS KAKENHI Grant Numbers JP15H05122 and JP17K15340. Further field research also fully supported by the ITTO Fellowship Program 2019 Ref Number 063/18A. We also thank field teams of Kupang Forestry Research and Development researchers and local community leaders who helped our field research.

\section{References}

Agu, Y. P. E. S., \& Neonbeni, E. Y. (2019). Identifikasi model pengelolaan lahan kering dataran tinggi berbasis agroforestri tradisional di Pulau Timor. Savana Cendana, 4(01), 12-16. https://doi.org/10.32938/sc.v4i01.460

[BBKSDA NTT] Balai Besar Konservasi Sumber Daya Alam Nusa Tenggara Timur. (2019). Profil CA Mutis Timau. Retrieved from http://bbksdantt.menlhk.go.id/

Benjamin, C. E. (2008). Legal pluralism and decentralization: Natural resource management in Mali. World Development, 36(11), 2255-2276. https://doi.org/ 10.1016/j.worlddev.2008.03.005

[BPS] Badan Pusat Statistik. (2019). Statistik Indonesia 2019. Retrieved from https://www.bps.go.id/publication

Burns, P. (2004). The Leiden legacy: Concepts of law in Indonesia. Leiden: KITLV Press.

Crouch, M. (2013). Review essay: Legal pluralism in Indonesia. Australian Journal of Asian Law, 14(1).

Dako, F. X., Purwanto, R. H., Faida, L. R. W., \& Sumardi, S. S. (2019). Tipologi pola konsumsi pangan untuk menjaga ketahanan pangan masyarakat sekitar kawasan hutan lindung Mutis Timau KPH Kabupaten Timor Tengah Selatan. Jurnal Ketahanan Nasional, 25(1), 92. https://doi.org/10.22146/jkn.39544

Fasseur, C. (2007). Colonial dilemma: Van Vollenhoven and the struggle between adat law and Western law in Indonesia. In The Revival of Tradition in Indoesian Politics (pp. 50-67).

Fisher, L., Moeliono, I., \& Wodicka, S. (1999). The Nusa Tenggara uplands, Indonesia: Multiple-site lessons in conflict management. In D. Buckles (Ed.), Cultivating peace: Conflict and collaboration in natural resource management (pp. 61-80). World Bank, IDRC.

Graziani M., \& Burnham P. (2005). Legal pluralism in the rain forests of South-eastern Cameroon. In $\mathrm{K}$. Homewood K. (Eds.), Rural Resources \& Local Livelihoods in Africa, (pp. 177-197). New York: Palgrave Macmillan. https://doi.org/10.1007/978-1-13706615-2 9

Griffiths, J. (1986). What is legal pluralism? The Journal of
Legal Pluralism and Unofficial Law, 18(24), 1-55.

Griffiths, J. (2015). Legal pluralism. In J. D. Wright (Ed.), International encyclopedia of the social \& behavioral sciences (2nd ed., pp. 757-761). Elsevier. https://doi.org/ 10.1016/B978-0-08-097086-8.86073-0

Hayes, T. M. (2006). Parks, people, and forest protection: An institutional assessment of the effectiveness of protected areas. World Development, 34(12), 2064-2075. https://doi.org/10.1016/j.worlddev.2006.03.002

Hidayat, H., Yogaswara, H., Herawati, T., Blazey, P., Wyatt, S., \& Howitt, R. (2018). Forests, law and customary rights in Indonesia: Implications of a decision of the Indonesian Constitutional Court in 2012. Asia Pacific Viewpoint, 59(3), 293-308. https://doi.org/10.1111/apv. 12 s 207

[IUCN] International Union for Conservation of Nature. (2008). Guidelines for applying protected area management categories. Retrieved from https://portals. iucn.org/library/sites/library/files/documents/PAG021.pdf

Jentoft, S., Bavinck, M., Johnson, D. S., \& Thomson, K. T. (2009). Fisheries co-management and legal pluralism: How an analytical problem becomes an institutional one. Human Organization, 68(1), 27-38.

Jepson, P., \& Whittaker, R. J. (2002). Histories of protected areas: Internationalisation of conservationist values and their adoption in the Netherlands Indies (Indonesia). Environment and History, 8(2), 129-172.

[Komnas HAM] Komisi Nasional Hak Asasi Manusia. (2016). Konflik agraria masyarakat hukum adat atas wilayahnya di kawasan hutan. Jakarta: Komnas HAM.

Kurniadi, R., \& Rumboko, L. (2016). Implementasi kebijakan silvopastur di Cagar Alam Gunung Mutis dan perlawanan masyarakat lokal. Jurnal Ilmu Sosial dan Ilmu Politik, 19(2), 169. https://doi.org/10.22146/ jsp. 10852

Kurniawan, M., \& Iswandono, E. (2018). Tabukah Cagar Alam Mutis berubah fungsi? Kupang: BBKSDANTT.

Lentz, C., \& Bowe, M. (1998, June 10-14). Environmental management in Gunung Mutis: A case study from Nusa Tenggara, Indonesia [Paper presentation]. The International Association for the Study of Common Property, Vancouver, BC, Canada.

Lund, C., \& Rachman, N. F. (2018). Indirect recognition. Frontiers and territorialization around Mount HalimunSalak National Park, Indonesia. World Development, 101(40), 417-428. https://doi.org/10.1016/j.worlddev. 2017.04 .003

Maiwa, A., Umar, S., Golar, G., \& Rahman, A. (2018). Resolusi konflik dalam pengelolaan Taman Nasional Lore Lindu. Jurnal Warta Rimba, 6(2). 47-54. 
McWilliam, A. (2006). Historical reflections on customary land rights in Indonesia. Asia Pacific Journal of Anthropology, 7(1), 45-64. https://doi.org/10.1080/ 14442210600551859

Meinzen-Dick, R., \& Nkonya, L. (2005). Understanding legal pluralism in water rights: Lessons from Africa and Asia. African Water Laws Workshop: Plural Legislative Frameworks for Rural Water Management in Africa.

Merry, S. E. (1988). Legal pluralism. Law \& Society Review, 22(5), 869-896.

[MoEF] Ministry of Environment and Forestry. (2020). Sejarah KSDAE. Retrieved from http://ksdae.menlhk. go.id/sejarah-ksdae.html

Myers, R., \& Muhajir, M. (2015). Searching for justice: Rights vs 'benefits' in Bukit Baka Bukit Raya National Park, Indonesia. Conservation and Society, 13(4), 370-381.

Myers, R., Intarini, D., Sirait, M. T., \& Maryudi, A. (2017). Claiming the forest: Inclusions and exclusions under Indonesia's 'new' forest policies on customary forests. Land Use Policy, 66, 205-213. https://doi.org/10.1016/j. landusepol.2017.04.039

Nordholt, H. S. (1971). The political system of the Atoni of Timor. Leiden: Brill Publishing.

Nurjaya, N. (2005). Sejarah hukum pengelolaan hutan di Indonesia. Jurisprudence, 2(1), 35-55.

Ormeling, F. J. (1955). The Timor problem. A geographical interpretation of an underdeveloped island [dissertation]. Jakarta-Groningen: JB Wolters.

Peluso, N. L. (1992). Rich forests, poor people: Resource control and resistance in Java. California: University of California Press.

Pujiono, E., Sadono, R., Hartono, \& Imron, M. A. (2019). Assessment of causes and future deforestation in the mountainous tropical forest of Timor Island, Indonesia. Journal of Mountain Science, 16(10), 2215-2231. https://doi.org/10.1007/s11629-019-5480-1

Riggs, R. A., Sayer, J., Margules, C., Boedhihartono, A. K., Langston, J. D., \& Sutanto, H. (2016). Forest tenure and conflict in Indonesia: Contested rights in Rempek Village, Lombok. Land Use Policy, 57, 241-249. https://doi.org/10.1016/j.landusepol.2016.06.002

Riwu Kaho, N., \& Marimpan, L. (2014). Pemetaan pola kebakaran berbasis fire regime di Cagar Alam Gunung Mutis, Timor Barat, Nusa Tenggara Timur. Buletin Leguminosae, 19.

Roth, D. (2011). The Subak in diaspora: Balinese farmers and the Subak in South Sulawesi. Human Ecology, 39(1), 55-68. https://doi.org/10.1007/s10745-010-9374-7

Salim, A. (2010). Dynamic legal pluralism in Indonesia: Contested legal orders in contemporary Aceh. The Journal of Legal Pluralism and Unofficial Law, 42(61), 1-29. https://doi.org/10.1080/07329113.2010.10756640

Sivaramakrishnan, K. (1995). Colonialism and forestry in India: Imagining the past in present politics. Comparative Studies in Society and History, 37(1), 3-40. https://doi.org/10.2307/179375

Sopian, N. L. (2015). Informal dispute resolution based on adat law: A case study of land dispute in Flores, East Nusa Tenggara, Indonesia. Indonesia Law Review, 5(2), 106. https://doi.org/10.15742/ilrev.v5n2.157

Stroomberg, J. (2018). Hindia Belanda 1930. Yogyakarta: IRCiSoD.

Suartika, G. A. M. (2007). Territoriality and the market system-Adat land vs. state regulations on land matters in Bali. Habitat International, 31(2), 167-176. https://doi.org/10.1016/j.habitatint.2006.11.001

Vandergeest, P., \& Peluso, N. L. (1995). Territorialization and state power in Thailand. Theory and Society, 24(3), 385-426. https://doi.org/10.1007/BF00993352

Vandergeest, P., \& Peluso, N. L. (2015). Political forests. In R. L. Bryant (Ed.), The International Handbook of Political Ecology (pp. 162-175). London: Edward Elgar Publishing.

Wibowo, L., Murdiati. R., C., Race, D., \& Murdiningrum, Y. (2012). Forest policy and legal pluralism: Case study in Luwu District, Indonesia. Indonesia Law Review, 2(1), 122.

Wirartha, I. M. (2006). Metode penelitian sosial ekonomi. Yogyakarta: Andi Offset.

Yudistira, P. (2014). Sang pelopor: Peranan Dr. S. H. Koorders dalam sejarah perlindungan alam di Indonesia. Jakarta: Direktorat Kawasan Konservasi dan Bina Hutan Lindung, Direktorat Jenderal Perlindungan Hutan dan Konservasi Alam, Kementerian Lingkungan Hidup dan Kehutanan. 